\title{
Analysis of the Hemagglutinin and Neuraminidase Genes of Human Influenza A/H3N2 Viruses Circulating in Iran between 2005 and 2007: Antigenic and Phylogenetic Relationships to Vaccine Strains
}

\author{
J. Yavarian ${ }^{a} \quad$ T. Mokhtari-Azad ${ }^{a} \quad$ S.A. Nadji ${ }^{b} \quad$ H. Zeraati ${ }^{a} \quad$ M. Naseri ${ }^{a}$ \\ a School of Public Health, Tehran University of Medical Sciences, and 'b Virology Research Center, NRITLD, \\ Masih Daneshvari Hospital, Shahid Beheshti University Medical Center, Tehran, Iran
}

\section{Key Words}

Influenza A/H3N2 virus • Iranian isolates • Antigenic variations $\cdot$ Surface glycoproteins

\begin{abstract}
Objectives: To study the antigenic variations in influenza A/H3N2 viruses circulating in Iran for characterization and phylogenetic relationships to vaccine strains. Methods: RT$\mathrm{PCR}$, full sequencing of hemagglutinin (HA) and neuraminidase (NA) genes and analysis by sequence handling and phylogenetic programs were done. Results: The HA sequences of 2007 isolates fell within the clade represented by the HA of $A /$ Brisbane/10/07 and characterized by the amino acid changes relative to the HA of A/Wisconsin/67/05, G50E and $\mathrm{K} 140 \mathrm{l}$. The only isolate in $2006 \mathrm{fell}$ within $\mathrm{A} / \mathrm{Berlin} / 02 / 06$ with $\mathrm{V} 112 \mathrm{I}$ and K173E changes. The 2005 isolates characterized by Y159F, S189N and S227P changes within A/California/07/04. In all isolates we had E190D which is important because this was responsible for the loss of ability of $\mathrm{A} / \mathrm{H} 3 \mathrm{~N} 2$ viruses to bind to chicken red blood cells. There were some substitutions in the antigenic sites of the HA. Similar to other studies, conserved residues for catalytic sites and also framework sites of NA supporting the catalytic residues were detected. We had some changes in the variable regions of the NA head
\end{abstract}

domain. Conclusion: Comparison between Iranian viruses and vaccine strains showed high similarity between them and vaccine strains used in the northern hemisphere.

Copyright $\odot 2010$ S. Karger AG, Basel

\section{Introduction}

Influenza A viruses are negative-stranded RNA viruses belong to the Orthomyxoviridae family [1]. They have two surface glycoproteins, hemagglutinin (HA) and neuraminidase (NA). 16 distinct subtypes of HA and 9 subtypes of NA have been recognized so far. Based on the antigenic properties of these two glycoproteins, influenza viruses are classified into different subtypes [2].

The HA glycoprotein is constructed of two domains: globular head (composed of most of the HAl polypeptide of HA) and long fibrous stem (comprised mostly of the HA2 polypeptide). The HA1 segment of the influenza HA protein is the most rapidly evolving region of the virus and plays a major role in viral attachment and evasion from neutralizing antibody responses [3]. On the globular head of $\mathrm{A} / \mathrm{H} 3 \mathrm{~N} 2$ viruses five antigenic sites (A-E) have been identified [3-5] where antibody binding can occur $[6,7] .18$ codons in the HAl segment of the HA

\section{KARGER}

Fax +41613061234 E-Mail karger@karger.ch www.karger.com
(C) 2010 S. Karger AG, Basel

$0300-5526 / 10 / 0532-0133 \$ 26.00 / 0$

Accessible online at:

www.karger.com/int
T. Mokhtari-Azad

WHO Influenza Centre, School of Public Health

Tehran University of Medical Sciences, Porsina Ave, Keshavarz Blvd

PO Box 6446-14155, Tehran (Iran)

Tel./Fax +98 218896 2343, E-Mail mokhtari@sina.tums.ac.ir 
Table 1. List of primers used for RT-PCR and sequencing

\begin{tabular}{|c|c|c|}
\hline Gene name & Primer & Sequence $5^{\prime}-3^{\prime}$ \\
\hline \multicolumn{3}{|l|}{$H 3$} \\
\hline \multirow[t]{4}{*}{ HA1 } & H3HAF6* & AAGCAGGGGATAATTCTATTAACC \\
\hline & H3HAF567 & CTGAACGTGACTATGCCAAACAAT \\
\hline & H3AR650 & TTGGTCACTGTCCGTACTCGGGTG \\
\hline & H3HAR1075* & AACCGTACCAACCRTCCACCATTC \\
\hline \multirow[t]{5}{*}{ HA2 } & H3HAF567* & CTGAACGTGACTATGCCAAACAAT \\
\hline & H3A1F1 & ATGAAGACTATCATTGCTTTCAGC \\
\hline & $\mathrm{H} 3 \mathrm{~A} 2 \mathrm{~F} 1$ & AGGCATATTCGGCGCAATCGCAGG \\
\hline & H3HAR1075 & AACCGTACCAACCRTCCACCATTC \\
\hline & H3A1R1* & GTCTATCATTCCCTCCCAACCATT \\
\hline \multicolumn{3}{|l|}{ N2 } \\
\hline \multirow[t]{6}{*}{ NA- $5^{\prime 1}$} & $\mathrm{~N} 2 \mathrm{~F} 1^{*}$ & AGCAAAAGCAGGAGTGAAAATGAA \\
\hline & $\mathrm{N} 2 \mathrm{~F} 387$ & CATGCGATCCTGACAAGTGTTATC \\
\hline & N2F754 & TGCTTCAGGAAAAGCTGATACTAA \\
\hline & N2R410 & GATAACACTTGCTAGGATCGCATG \\
\hline & N2R778 & TTAGTATCAGCTTTTTCTGAAGCA \\
\hline & N2R1104* & ATCCACACGTCATTTCCATCGTCA \\
\hline \multirow{5}{*}{ NA-3 ${ }^{\prime 1}$} & $\mathrm{~N} 2 \mathrm{~F} 387^{*}$ & CATGCGATCCTGACAAGTGTTATC \\
\hline & N2F754 & TGCTTCAGGAAAAGCTGATACTAA \\
\hline & N2R778 & TTAGTATCAGCTTTTTCTGAAGCA \\
\hline & N2R1104 & ATCCACACGTCATTTCCATCGTCA \\
\hline & $\mathrm{N} 2 \mathrm{R} 1^{*}$ & TTCTAAAATTGCGAAAGCTTATAT \\
\hline
\end{tabular}

genes of human influenza A/H3N2 appear to be under positive selection to change the amino acids they encode [8-11].

NA is the second major glycoprotein of influenza $A$ viruses. NA is a tetramer comprised of a bulky head attached to a slender stalk [12]. Viral NA removes terminal sialic acids from glycoconjugates on both cell receptors and the viral HA, thereby allowing the release of progeny viruses from infected cells [13-15].

The influenza virus glycoproteins are well known to undergo antigenic drift and shift. Antigenic drift occurs because of the point mutations result in amino acid changes in the two surface glycoproteins and enables viruses to escape from preexisting immunity and emergence of new antigenic variants. These new variants are the cause of the worldwide seasonal influenza epidemics. Because of the high morbidity and mortality due to influenza epidemics, monitoring the antigenic variations in circulating influenza viruses is crucial for anticipating epidemics and vaccine design $[3,4,16]$.

Antigenic shift is a major change that results in the emergence of a new subtype and usually causes a pandemic, such as the three pandemics of the 20th century and the currently emerging pandemic of the 21st century [6].

The variability in both the emerging pandemic and seasonal influenza viruses is a considerable problem for the production of an effective vaccine and the reassessment of vaccine composition according to the circulating strains.

In this study sequencing analysis of the HA and NA of influenza A/H3N2 was performed on viruses from the Islamic Republic of Iran, in order to describe the virus variation and mutations which differ from the annually recommended vaccine strains in this region of the world.

\section{Materials and Methods}

\section{Clinical Samples}

Clinical samples were collected from 432 individuals who where diagnosed with influenza-like illness between January 2005 and October 2008. No A/H3N2 viruses were isolated during 2008 which may have been because A/H1N1 viruses predominated in Iran during that season.

The specimens were provided by Iran Ministry of Health and sent to the National Influenza Centre at Tehran University of Medical Sciences.

\section{Virus Screening and Isolation}

In order to screen the influenza virus A/H3N2, RNA extraction and real-time PCR were done on samples and the positive ones were inoculated into MDCK cells for virus isolation and culture.

\section{Genetic and Phylogenetic Analysis}

All positive samples were subjected to HA and NA gene sequencing at the WHO Influenza Centre, National Institute for Medical Research, London. RNA was extracted from $140 \mu$ l of cell culture supernatants (in case of positive cell culture) or from 140 $\mu \mathrm{l}$ of clinical samples using the Qiagen viral RNA Mini Kit. The full HA and NA genes were amplified using the primers shown in table 1. RT-PCR conditions with the Qiagen One Step RT-PCR Kit were as follows: $\mathrm{cDNA}$ synthesis $\left(60^{\circ}\right.$ for $1 \mathrm{~min}, 50^{\circ}$ for $30 \mathrm{~min}$ and $95^{\circ}$ for $\left.15 \mathrm{~min}\right)$, followed by 40 amplification cycles consisting of denaturation at $94^{\circ}$ for $30 \mathrm{~s}$, primer annealing at $50^{\circ}$ for $30 \mathrm{~s}$ and extension at $72^{\circ}$ for $1 \mathrm{~min}$ with a final extension at $72^{\circ}$ for $10 \mathrm{~min}$. The expected size of the PCR products were analyzed by electrophoresis using $1 \%$ agarose gels.

The PCR products were purified using GFX PCR DNA and Gel Bond Purification Kit (GE Healthcare). DNA sequencing was performed using the BigDye Terminator V1.1 Cycle Sequencing Kit. After ethanol precipitation the reactions were resolved on the Mega BACE sequencing machine and the HA and NA sequences were edited with the Staden package (http://www.sanger.ac.uk/ Software/production/staden/) and aligned using the Wisconsin package (http://accelrys.com/products/gcg_wisconsin_package or http//www.gcg.com). Phylogenetic trees were constructed by means of the Neighbor-Joining method using the Wisconsin 
Fig. 1. Phylogram of HA and NA genes of Iranian $\mathrm{H} 3 \mathrm{~N} 2$ viruses.

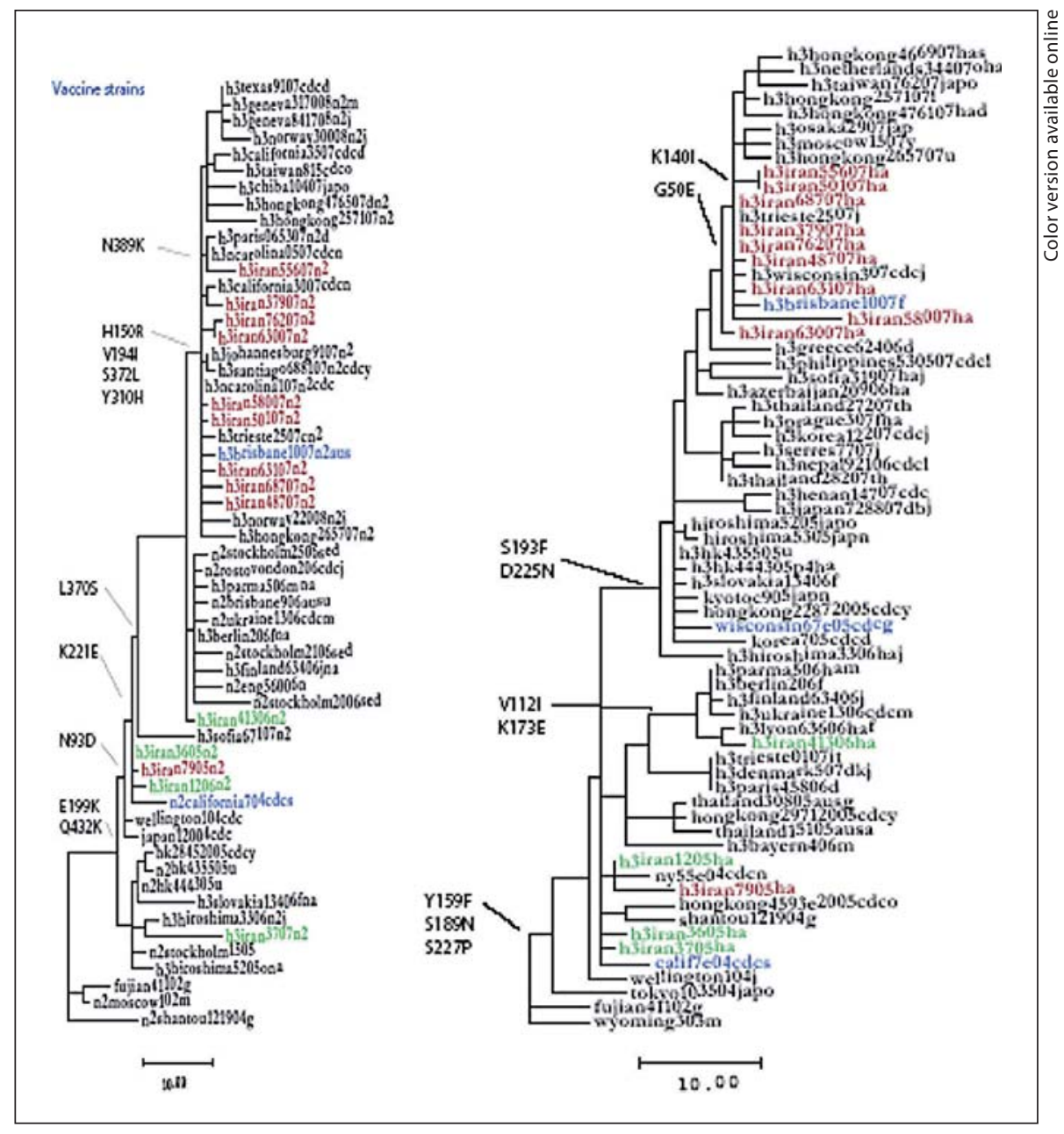

package. The lengths of the horizontal lines are proportional to the numbers of nucleotide differences, as indicated by the bar (fig. 1). All sequences determined by this study have been deposited in the GenBank database under accession numbers FJ769866-FJ769915.

\section{Results}

14 A/H3N2 subtypes were found in all throat swab specimens from patients with influenza-like illness between 2005 and 2008. We failed to isolate the A/H3N2 subtype during this study in 2008. The full genome of HA and NA genes were sequenced and analyzed. The deduced amino acid comparison between our viruses and vaccine strains showed high similarity between them and reference strains and vaccine strains which were used in the northern hemisphere between 2005 and 2007.
Phylogenetic analysis for HA and NA of A/H3N2 isolates showed continuous evolution and similarity to the vaccine strains of each 3 years. Beside the vaccine strains, Iranian A/H3N2 viruses were almost exclusively similar to the strains which were circulating during each of those years all over the world.

Five altered amino acids were detected at the antigenic sites $\mathrm{A}, \mathrm{B}, \mathrm{C}$ and $\mathrm{E}$ of HA1 with different changes in three consecutive years (table 2).

11 Glycosylation sequons [17] which are N-linked glycosylation sites composed of Asn-X-Ser/Thr were found to be similar to the other studies: in this sequence $\mathrm{X}$ can be any amino acid except for aspartic acid and proline. In some strains there were mutations which have changed N-linked glycosylation sites, for instance A/Tehran/79/05 had N8T and A/Tehran/487/07 had N63K (fig. 2), both resulting in the loss of the glycosylation sequon. All isolates had an asparagine residue at position 145 (K145N), 
Table 2. Amino acid substitutions in the hemagglutinin gene of influenza virus A/H3N2 isolated in Iran

\begin{tabular}{|c|c|c|c|c|c|c|c|c|c|c|c|c|c|c|c|c|c|c|c|c|c|}
\hline \multirow[t]{2}{*}{ Isolate name } & \multirow{2}{*}{$\begin{array}{l}\text { Date of } \\
\text { collection }\end{array}$} & \multicolumn{20}{|c|}{ Amino acid position of HA gene } \\
\hline & & $50(\mathrm{C})$ & 112 & $140(\mathrm{~A})$ & $173(\mathrm{E})$ & 193(B) & 199(B) & 225 & 375 & $121^{*}$ & 8 & 63 & 145(A) & 159(B) & 172 & 189(B) & 190(D) & 209 & 226(D) & 227 & 278 \\
\hline $\mathrm{A} / \mathrm{Iran} / 12 / 05$ & $25 / 2 / 2005$ & G & $\mathrm{V}$ & K & $\mathrm{K}$ & S & S & $\mathrm{D}$ & $\mathrm{N}$ & $\mathrm{R}$ & $\mathrm{N}$ & $\mathrm{N}$ & $\mathrm{N}$ & $\mathrm{F}$ & Q & $\mathrm{N}$ & $\mathrm{D}$ & S & I & $\mathrm{P}$ & $\mathrm{N}$ \\
\hline A/Iran/36/05 & $12 / 2 / 2005$ & G & $\mathrm{V}$ & $\mathrm{K}$ & $\mathrm{K}$ & S & $\mathrm{S}$ & $\mathrm{D}$ & $\mathrm{N}$ & $\mathrm{R}$ & $\mathrm{N}$ & $\mathrm{N}$ & $\mathrm{N}$ & $\mathrm{F}$ & Q & $\mathrm{N}$ & $\mathrm{D}$ & S & I & $\mathrm{P}$ & $\mathrm{N}$ \\
\hline A/Iran/37/05 & $13 / 2 / 2005$ & G & $\mathrm{V}$ & $\mathrm{K}$ & $\mathrm{K}$ & $\mathrm{S}$ & $\mathrm{S}$ & $\mathrm{D}$ & $\mathrm{N}$ & $\mathrm{R}$ & $\mathrm{N}$ & $\mathrm{N}$ & $\mathrm{N}$ & $\mathrm{F}$ & Q & $\mathrm{N}$ & $\mathrm{D}$ & $\mathrm{S}$ & I & $\mathrm{P}$ & $\mathrm{N}$ \\
\hline A/Iran/79/05 & $4 / 1 / 2005$ & G & $\mathrm{V}$ & $\mathrm{K}$ & $\mathrm{K}$ & $\mathrm{S}$ & $\mathrm{S}$ & $\mathrm{D}$ & $\mathrm{N}$ & $\mathrm{R}$ & $\mathrm{T}$ & $\mathrm{N}$ & $\mathrm{N}$ & $\mathrm{F}$ & Q & $\mathrm{N}$ & $\mathrm{D}$ & $\mathrm{S}$ & I & $\mathrm{P}$ & $\mathrm{N}$ \\
\hline A/Iran/413/06 & $15 / 2 / 2006$ & G & I & $\mathrm{K}$ & E & $\mathrm{S}$ & $\mathrm{P}$ & $\mathrm{D}$ & $\mathrm{D}$ & $\mathrm{R}$ & $\mathrm{N}$ & $\mathrm{N}$ & $\mathrm{N}$ & $\mathrm{F}$ & $\mathrm{R}$ & $\mathrm{N}$ & $\mathrm{D}$ & $\mathrm{S}$ & I & $\mathrm{P}$ & $\mathrm{K}$ \\
\hline $\mathrm{A} / \mathrm{Iran} / 580 / 07$ & $27 / 1 / 2007$ & $\mathrm{E}$ & $\mathrm{V}$ & I & $\mathrm{K}$ & $\mathrm{F}$ & $S$ & $\mathrm{~N}$ & $\mathrm{D}$ & K & $\mathrm{N}$ & $\mathrm{N}$ & $\mathrm{N}$ & $\mathrm{F}$ & Q & $\mathrm{N}$ & $\mathrm{D}$ & $\mathrm{S}$ & I & $\mathrm{P}$ & $\mathrm{N}$ \\
\hline $\mathrm{A} / \mathrm{Iran} / 487 / 07$ & $21 / 1 / 2007$ & $\mathrm{E}$ & $\mathrm{V}$ & I & $\mathrm{K}$ & $\mathrm{F}$ & $S$ & $\mathrm{~N}$ & $\mathrm{D}$ & K & $\mathrm{N}$ & $\mathrm{K}$ & $\mathrm{N}$ & $\mathrm{F}$ & Q & $\mathrm{N}$ & $\mathrm{D}$ & S & I & $\mathrm{P}$ & $\mathrm{N}$ \\
\hline $\mathrm{A} / \operatorname{Iran} / 631 / 07$ & $2 / 2 / 2007$ & $\mathrm{E}$ & $\mathrm{V}$ & I & $\mathrm{K}$ & $\mathrm{F}$ & $\mathrm{S}$ & $\mathrm{N}$ & $\mathrm{D}$ & $\mathrm{K}$ & $\mathrm{N}$ & $\mathrm{N}$ & $\mathrm{N}$ & $\mathrm{F}$ & Q & $\mathrm{N}$ & $\mathrm{D}$ & S & I & $\mathrm{P}$ & $\mathrm{N}$ \\
\hline $\mathrm{A} / \mathrm{Iran} / 687 / 07$ & $6 / 2 / 2007$ & $\mathrm{E}$ & $\mathrm{V}$ & I & $\mathrm{K}$ & $\mathrm{F}$ & $S$ & $\mathrm{~N}$ & $\mathrm{D}$ & K & $\mathrm{N}$ & $\mathrm{N}$ & $\mathrm{N}$ & $\mathrm{F}$ & Q & $\mathrm{N}$ & $\mathrm{D}$ & S & I & $\mathrm{P}$ & $\mathrm{N}$ \\
\hline $\mathrm{A} / \operatorname{Iran} / 379 / 07$ & $12 / 1 / 2007$ & $\mathrm{E}$ & $\mathrm{V}$ & I & $\mathrm{K}$ & $\mathrm{F}$ & $S$ & $\mathrm{~N}$ & $\mathrm{D}$ & K & $\mathrm{N}$ & $\mathrm{N}$ & $\mathrm{N}$ & $\mathrm{F}$ & $\mathrm{Q}$ & $\mathrm{N}$ & $\mathrm{D}$ & S & I & $\mathrm{P}$ & $\mathrm{N}$ \\
\hline $\mathrm{A} / \mathrm{Iran} / 762 / 07$ & $11 / 2 / 2007$ & $\mathrm{E}$ & $\mathrm{V}$ & I & $\mathrm{K}$ & $\mathrm{F}$ & S & $\mathrm{N}$ & $\mathrm{D}$ & K & $\mathrm{N}$ & $\mathrm{N}$ & $\mathrm{N}$ & $\mathrm{F}$ & Q & $\mathrm{N}$ & $\mathrm{D}$ & S & I & $\mathrm{P}$ & $\mathrm{N}$ \\
\hline $\mathrm{A} / \mathrm{Iran} / 501 / 07$ & $19 / 1 / 2007$ & $\mathrm{E}$ & $\mathrm{V}$ & I & K & $\mathrm{F}$ & S & $\mathrm{N}$ & $\mathrm{D}$ & K & $\mathrm{N}$ & $\mathrm{N}$ & $\mathrm{N}$ & $\mathrm{F}$ & Q & $\mathrm{N}$ & $\mathrm{D}$ & $\mathrm{T}$ & I & $\mathrm{P}$ & $\mathrm{N}$ \\
\hline A/Iran/556/07 & $26 / 2 / 2007$ & $\mathrm{E}$ & $\mathrm{V}$ & I & $\mathrm{K}$ & $\mathrm{F}$ & S & $\mathrm{N}$ & $\mathrm{D}$ & $\mathrm{K}$ & $\mathrm{N}$ & $\mathrm{N}$ & $\mathrm{N}$ & $\mathrm{F}$ & Q & $\mathrm{N}$ & $\mathrm{D}$ & $\mathrm{T}$ & I & $\mathrm{P}$ & $\mathrm{N}$ \\
\hline $\mathrm{A} / \operatorname{Iran} / 630 / 07$ & $2 / 2 / 2007$ & $\mathrm{E}$ & $\mathrm{V}$ & I & $\mathrm{K}$ & $\mathrm{F}$ & $\mathrm{S}$ & $\mathrm{N}$ & $\mathrm{D}$ & $\mathrm{K}$ & $\mathrm{N}$ & $\mathrm{N}$ & $\mathrm{N}$ & $\mathrm{F}$ & $\mathrm{Q}$ & $\mathrm{N}$ & $\mathrm{D}$ & $S$ & I & $\mathrm{P}$ & $\mathrm{N}$ \\
\hline
\end{tabular}

A, B, C and E are the antigenic sites. * HA2 numbering.

which created a glycosylation site in antigenic site A, similar to the previous studies [6, 18-20]. K145N substitution is characteristic of viruses similar to A/California/7/2004. This change is an exchange of a positive to a polar amino acid and there is some evidence that this might be responsible for an antigenic drift at that time [20,21].

In all isolates E190D was detected which is important because some experiments revealed that this change was responsible for the loss of ability of $\mathrm{A} / \mathrm{H} 3 \mathrm{~N} 2$ viruses to bind to chicken red blood cells [22]. In 2005 and 2006 isolates there were asparagine in position 193 (F193S): 193 is located in antigenic site $\mathrm{B}$ and is able to influence the antigenicity of the HA [19].

Some substitutions similar to the previous reports were Y159F, S189N in antigenic site B and V226I, S227P in antigenic site D. Ile-226, Pro-227 and Ser-228 are responsible for the NeuAc $22,6 \mathrm{Gal}$ linkage which is very important in receptor binding [21, 23, 24].

One substitution in HA1, S209T in antigenic site D, was observed in two isolates of 2007 (table 2).

Two mutations, i.e. N278K which is typical of Lyon/636 and Q172R (HA2 numbering), were found in the one isolate detected in 2006. It fell within the phylogenetic group characterized by amino acid changes V112I and K173E and represented by A/Berlin/2/2006 and A/Lyon/636/ 2006. Some other changes have been found which are shown in table 2 . These changes were mostly at the antigenic sites and they were important in the antigenic drift. HA phylogeny showed the HA sequences were at the same branch of vaccine strains and there was no evidence of a significant distinct subclade of viruses circulating in Iran over the period of study (fig. 1).

In comparison of nucleotide and deducted amino acid sequences of NA from these viruses, a high degree of similarity was found between these isolates and vaccine strains in each year. Similar to the other studies $[6,25]$ conserved residues for catalytic sites (R118, D151, R152, R224, E276, R292, R371 and Y406) and also framework sites supporting the catalytic residues (E119, R156, W178, D198, I222, E227, H274, E277, N294 and E425) were detected. We found some different changes in NA which are shown in table 3.

The variable regions in the NA head domain are amino acids $140-155,328-370$ and to a lesser extent 381-403 $[26,27]$ and we also found some changes at these locations (table 3). The NA sequences of these viruses fell into the corresponding clade and were similar to those of equivalent viruses circulating in those 3 years and there was no evidence for the emergence of a significant distinct subclade (fig. 1).

Fig. 2. Amino acid comparison between HA protein of Iranian $\mathrm{H} 3 \mathrm{~N} 2$ viruses and vaccine strains. Lines represent amino acids similar to the consensus. The N-linked glycosylation sites are shown in grey (red in the online version). 


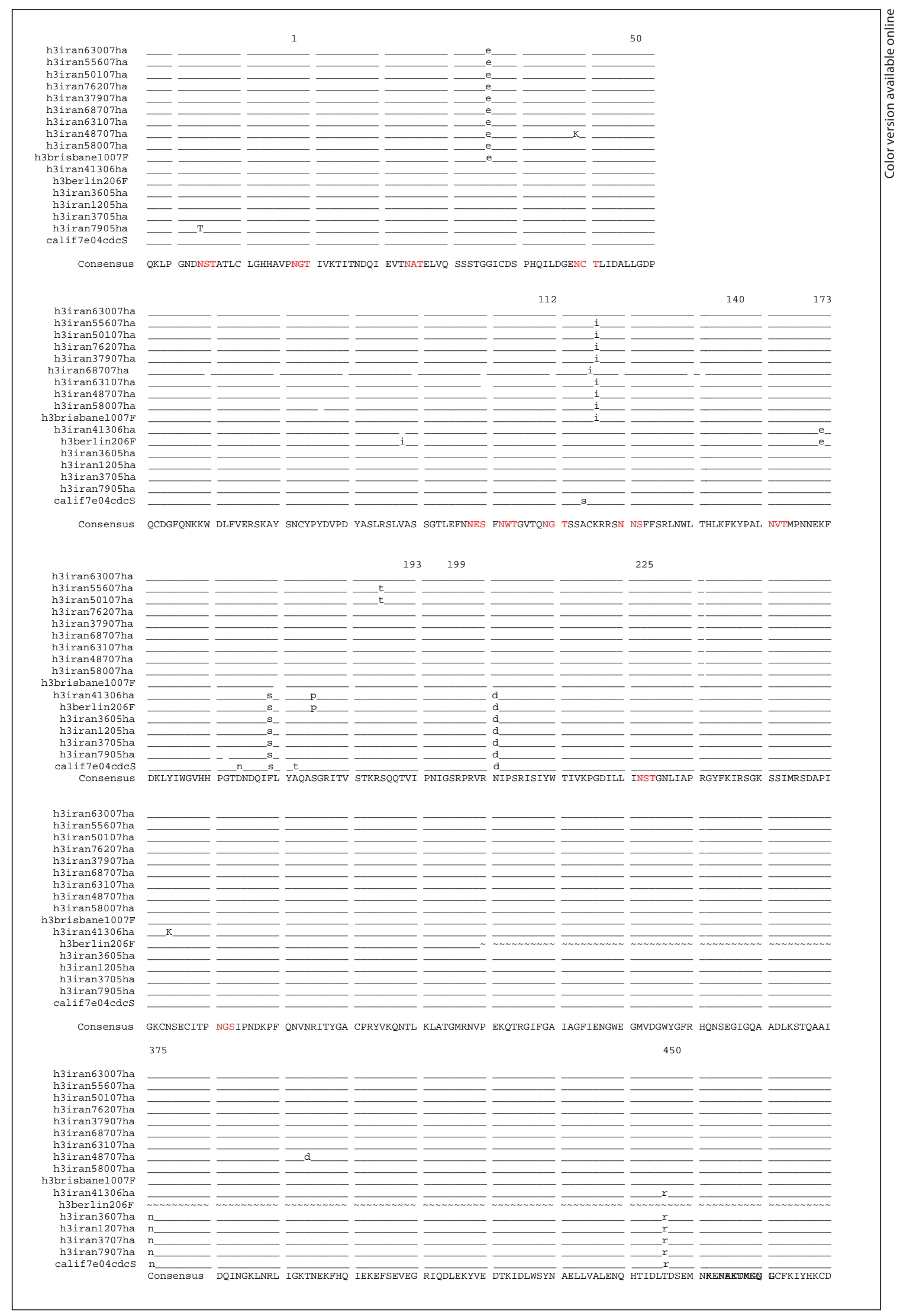


Table 3. Amino acid substitutions in the neuraminidase gene of influenza virus $\mathrm{A} / \mathrm{H} 3 \mathrm{~N} 2$ isolated in Iran

\begin{tabular}{lllllllll}
\hline \multirow{2}{*}{ Isolate name } & \multirow{2}{*}{$\begin{array}{l}\text { Date of } \\
\text { collection }\end{array}$} & \multicolumn{7}{c}{ Amino acid position of HA gene } \\
\cline { 5 - 8 } & & 150 & 194 & 310 & 310 & 372 & 387 \\
\hline A/Iran/12/05 & $25 / 02 / 2005$ & $\mathrm{H}$ & $\mathrm{V}$ & $\mathrm{Y}$ & $\mathrm{L}$ & $\mathrm{S}$ & $\mathrm{N}$ \\
$\mathrm{A} / \mathrm{Iran} / 36 / 05$ & $12 / 02 / 2005$ & $\mathrm{H}$ & $\mathrm{V}$ & $\mathrm{Y}$ & $\mathrm{L}$ & $\mathrm{S}$ & $\mathrm{N}$ \\
A/Iran/37/05 & $13 / 02 / 2005$ & $\mathrm{H}$ & $\mathrm{V}$ & $\mathrm{Y}$ & $\mathrm{L}$ & $\mathrm{S}$ & $\mathrm{N}$ \\
A/Iran/79/05 & $04 / 01 / 2005$ & $\mathrm{H}$ & $\mathrm{V}$ & $\mathrm{Y}$ & $\mathrm{L}$ & $\mathrm{S}$ & $\mathrm{N}$ \\
A/Iran/413/06 & $15 / 02 / 2006$ & $\mathrm{R}$ & $\mathrm{I}$ & $\mathrm{H}$ & $\mathrm{S}$ & $\mathrm{L}$ & $\mathrm{N}$ \\
A/Iran/580/07 & $27 / 01 / 2007$ & $\mathrm{R}$ & $\mathrm{I}$ & $\mathrm{H}$ & $\mathrm{S}$ & $\mathrm{L}$ & $\mathrm{K}$ \\
A/Iran/487/07 & $21 / 01 / 2007$ & $\mathrm{R}$ & $\mathrm{I}$ & $\mathrm{H}$ & $\mathrm{S}$ & $\mathrm{L}$ & $\mathrm{K}$ \\
A/Iran/631/07 & $02 / 02 / 2007$ & $\mathrm{R}$ & $\mathrm{I}$ & $\mathrm{H}$ & $\mathrm{S}$ & $\mathrm{L}$ & $\mathrm{K}$ \\
A/Iran/687/07 & $06 / 02 / 2007$ & $\mathrm{R}$ & $\mathrm{I}$ & $\mathrm{H}$ & $\mathrm{S}$ & $\mathrm{L}$ & $\mathrm{K}$ \\
A/Iran/379/07 & $12 / 01 / 2007$ & $\mathrm{R}$ & $\mathrm{I}$ & $\mathrm{H}$ & $\mathrm{S}$ & $\mathrm{L}$ & $\mathrm{K}$ \\
A/Iran/762/07 & $11 / 02 / 2007$ & $\mathrm{R}$ & $\mathrm{I}$ & $\mathrm{H}$ & $\mathrm{S}$ & $\mathrm{L}$ & $\mathrm{K}$ \\
A/Iran/501/07 & $19 / 01 / 2007$ & $\mathrm{R}$ & $\mathrm{I}$ & $\mathrm{H}$ & $\mathrm{S}$ & $\mathrm{L}$ & $\mathrm{K}$ \\
A/Iran/556/07 & $26 / 02 / 2007$ & $\mathrm{R}$ & $\mathrm{I}$ & $\mathrm{H}$ & $\mathrm{S}$ & $\mathrm{L}$ & $\mathrm{K}$ \\
A/Iran/630/07 & $02 / 02 / 2007$ & $\mathrm{R}$ & $\mathrm{I}$ & $\mathrm{H}$ & $\mathrm{S}$ & $\mathrm{L}$ & $\mathrm{K}$ \\
\hline
\end{tabular}

\section{Discussion}

From January 2005 to October 2008, 432 specimens were collected of which $50(11.33 \%)$ were influenza B, 35 (8.10\%) were $\mathrm{A} / \mathrm{H} 1 \mathrm{~N} 1$, and 14 (3.24\%) were $\mathrm{A} / \mathrm{H} 3 \mathrm{~N} 2$ viruses. Generally all over the world there was a variable frequency of $\mathrm{A} / \mathrm{H} 1 \mathrm{~N} 1, \mathrm{~A} / \mathrm{H} 3 \mathrm{~N} 2$ and influenza $\mathrm{B}$ virus circulation in those years, e.g. according to the report by the WHO Influenza Centre in London: of some 800 influenza viruses isolated in 34 countries from February 2005 to 2006 , approximately half $(49 \%)$ were $\mathrm{A} / \mathrm{H} 3 \mathrm{~N} 2,17 \%$ were A/H1N1 and 34\% were influenza B. In 2006-2007 some 780 influenza viruses, isolated in 42 countries, were characterized. These included similar numbers of A/H1N1 (32\%), A/H3N2 (31\%) and B (37\%) viruses. During February to September 2007, influenza A/H1N1, $\mathrm{A} / \mathrm{H} 3 \mathrm{~N} 2$ and $\mathrm{B}$ viruses continued to circulate worldwide and caused outbreaks in many countries. Influenza $\mathrm{A} / \mathrm{H} 3 \mathrm{~N} 2$ viruses predominated overall and comprised roughly half of the viruses isolated. From 700 influenza viruses isolated in 30 countries during October 2007 to February 2008, the majority were A/H1N1 (77\%) and only a few (2\%) were of the $\mathrm{A} / \mathrm{H} 3 \mathrm{~N} 2$ subtype [28].

In the 14 samples of $\mathrm{A} / \mathrm{H} 3 \mathrm{~N} 2$ viruses, the changes seen in $\mathrm{HA}$ and NA were compared with vaccine strains. The HA sequences of 2005 isolates were characterized by Y159F, S189N and S227P changes within A/California/07/04. The only isolate in 2006 fell within A/Berlin/02/06 with V112I and K173E changes. The 2007 isolates fell within the clade represented by the HA of A/ Brisbane/10/07 and characterized by the amino acid changes relative to the $\mathrm{HA}$ of A/Wisconsin/67/05, G50E and K140I. We failed to isolate any A/H3N2 in 2008.

The HA1 segment showed higher changes in than HA2 because of its antigenic sites and receptor-binding properties as generally seen. Changes in antigenic sites are the center of interest because of the need for the continual update of influenza vaccines. The residues within the receptor-binding site are relatively conserved but the residue mainly responsible for NeuAc 2,6 Gal linkage specific for the H3 subtype, residue 226, was Ile-226 instead of Leu-226 as previously reported [6, 23, 29-32]. An amino acid substitution at position 145 which is located adjacent to antibody-binding site $\mathrm{A}$ and within a known glycosylation site results in a more accessible receptorbinding cleft located directly above residue 145 [20, 21]. $\mathrm{N}$-linked glycosylation is important because its presence or absence may cause a loss of function of the glycoprotein and may initiate and maintain folding, stability, transport, antigenicity and immunogenicity of the protein [6]. A virus containing HA with little carbohydrate modification can tightly bind the receptor, requiring greater NA activity to promote particle release. Conversely, an HA with more extensive glycosylation interacts weakly with receptors and requires a less active NA to facilitate release. Overall, the HA depends on a balance of glycosylation to mediate the proper folding of the HA, interaction of virus with receptor, and efficient particle release $[33,34]$.

In the context of the NA gene, conserved catalytic and framework sites of the enzyme as in previous studies have been found [6], but we, as expected, still found some 
changes in the NA of the viruses and showed a high similarity to vaccine strains in each year.

To date, molecular and phylogenetic analysis of influenza $\mathrm{A} / \mathrm{H} 3 \mathrm{~N} 2$ viruses spanning 3 consecutive years have not been reported in Iran. Comparison of the nucleotide and amino acid sequences of the HA and NA genes between $\mathrm{A} / \mathrm{H} 3 \mathrm{~N} 2$ isolates and the vaccine strains showed they are closely related to the vaccine strains recommended for those 3 years. Phylogenetic analyses showed that Iranian isolates are at the same branch of circulating viruses in the same year compatible with vaccine strains and there was no evidence of a significant distinct subclade of viruses circulating in Iran over the period of study.

Influenza vaccines are the most appropriate tools for preventing influenza infections, therefore the use of appropriate vaccine which has got the highest antigenic similarity to the viruses circulating in the country is very important so the continuous monitoring of the genetic and antigenic characteristics of influenza strains in circulation is an essential policy, not only for optimization of the annual influenza vaccine composition, but also for increasing our knowledge of the molecular epidemiology and evolutionary relations of influenza viruses. The data demonstrated that amino acid changes were limited to some key codons at or near antibody-binding sites A-E on the HA1 molecule. The changes at the antibody-binding site or receptor-binding site are crucial for antigenic drift, and it is important to monitor new $\mathrm{H} 3$ isolates for mutations in these sites.

In conclusion, this study has shown conserved sequences as well as some variations due to amino acid substitutions at the receptor-binding site and antigenic sites of the HA gene and some changes in the NA gene of Iranian $\mathrm{A} / \mathrm{H} 3 \mathrm{~N} 2$ strains which generally showed high similarity between them and the vaccine strains used in the northern hemisphere.

\section{Acknowledgements}

We would like to thank Dr. Alan Hay (director) and the entire staff of the WHO Influenza Centre, National Institute for Medical Research, Virology Department, Mill Hill, London, for helping us with the research. A part of this research was funded by Nahade Riasate Jomhoori under project number 58022/8.

\section{References}

1 Mokhtari-Azad T, Rezaie-Khollari F, Nadji AR, Salimi V, Noroozbabaie Z, Naseri M, Mirzaie AR, Saadatmand Z, Gouya MM, Esteghamati AR, Hamkar R: Comparison of multiplex nested RT-PCR with Virus isolation for detection of influenza viruses $A$ and B. Iran J Publ Health 2007;36(3):1-7.

-2 Webster RG, Bean WJ, Gorman OT, Chambers TM, Kawaoka Y: Evolution and ecology of influenza A viruses. Microbiol Rev 1992; $56: 152-179$

3 Wiley DC, Wilson IA, Skehel JJ: Structural identification of the antibody-binding sites of Hong Kong influenza hemagglutinin and their involvement in antigenic variation. $\mathrm{Na}$ ture 1981;289:373-378.

4 Underwood PA: Mapping of antigenic changes in the haemagglutinin of Hong Kong influenza (H3N2) strains using a large panel of monoclonal antibodies. J Gen Virol 1982;62:153-169.

5 Wilson IA, Cox NJ: Structural basis of immune recognition of influenza virus hemagglutinin. Annu Rev immunol 1990;8:737771.

6 Chutinimitkul S, Chieochansin T, Payungporn S, Samransamruajkit R, Hiranras T, Theamboonlers A, Poovorawan Y: Molecular characterization and phylogenetic analysis of H1N1 and H3N2 human influenza A viruses among infants and children in Thailand. Virus Res 2007;132:122-131.
7 Tinh Hien T, Thanh Liem N, Thi Dung N Thi San L, Phuong Mai P, et al: Avian influenza A (H5N1) in 10 patients in Vietnam. N Engl J Med 2004;350:1179-1188.

8 Bush RM, Bender CA, Subbarao K, Cox NJ, Fitch WM: Predicting the evolution of human influenza A. Science 1999;286:19211925.

$\checkmark 9$ Bush RM, Fitch WM, Bender CA, Cox NJ: Positive selection on the $\mathrm{H} 3$ hemagglutinin gene of human influenza virus A. Mol Biol Evol 1999;16:1457-1465.

10 Cross KJ, Wharton SA, Skehel JJ, Wiley DC, Steinhauer DA: Studies on influenza haemagglutinin fusion peptide mutants generated by reverse genetics. EMBO J 2001;20: 4432-4442.

11 Joshua BP, Dushoff J: Codon bias and frequency-dependent selection on the hemagglutinin epitopes of influenza A virus. Proc Natl Acad Sci USA 2003;100:7152-7157.

12 Varghese JN, Laver WG, Colman PM: Structure of the influenza virus glycoprotein antigen neuraminidase at 2.9 resolution. $\mathrm{Na}$ ture 1983;303:35-40.

13 Seto JT, Chang FS: Functional significance of sialidase during influenza virus multiplication. Virology 1966;30:731-737.

14 Palese P, Tobita K, Ueda M, Compans RW: Characterization of temperature sensitive influenza virus mutants defective in neuraminidase. Virology 1976;61:397-410.
15 Palese P, Compans RW: Inhibition of influenza virus replication in tissue culture by 2 deoxy-2,3-dehydro-N-trifluoroacetyl-neuraminic acid (FANA): mechanism of action. J Gen Virol 1976;33:159-163.

16 Keshtkar-Jahromi M, Argani H, Rahnavardi M, Mirchi E, Atabak SH, Tara SA, Gachkar L, Noori-Froothghe A, Mokhtari-Azad T: Antibody response to influenza immunization in kidney transplant recipients receiving either azathioprine or mycophenolate: a controlled trial. Am J Nephrol 2008;28:654660.

17 Helenius A, Aebi M: Roles of N-linked glycans in the endoplasmic reticulum. Annu Rev Biochem 2004;73:1019-1049.

18 Smith DJ, Lapedes AS, De Jong JC, Bestebroer TM, Rimmelzwaan GF, Osterhaus ADME, Fouchier RAM: Mapping the antigenic and genetic evolution of influenza virus. Science 2004;305:371-376.

19 Hungnes O: Early detection of A/California/7/2004-like A(H3N2) strains in Norway during the 2004-2005 season, and emergence of a novel $\mathrm{H} 3 \mathrm{~N} 2$ genetic sub-variant toward the end. Vaccine 2006;24:66946696

-20 Pechirra P, Gonçalves P, Arraiolos A, Coelho A, Rebelo-de-Andrade $\mathrm{H}$ : Characterization of influenza A/Fujian/411/2002(H3N2)-like viruses isolated in Portugal between 2003 and 2005. J Med Virol 2008;80:1624-1630. 
-21 Daum LT, Shaw MW, Klimov AI, et al: Influenza A (H3N2) outbreak, Nepal. Emerg Infect Dis 2005;11:1186-1191.

-22 Nobusawa E, Nakajima K, Kozuka S, Ishihara $\mathrm{H}$ : Change in receptor-binding specificity of recent human influenza A viruses (H3N2): a single amino acid change in hemagglutinin altered its recognition of sialyloligosaccharides. Virology 2000;278:587596.

-23 Widjaja L, Ilyushina N, Webster R, Webby R: Molecular changes associated with adaptation of human influenza A virus in embryonated chicken eggs. Virology 2006;350:137145.

-24 Lu B, Zhou H, Ye D, Kemble G, Jin H: Improvement of influenza A/Fujian/411/02 (H3N2) virus growth in embryonated chicken eggs by balancing the hemagglutinin and neuraminidase activities, using reverse genetics. J Virol 2005;79:6763-6771.
25 Colman PM, Hoyne PA, Lawrence MC: Sequence and structure alignment of paramyxovirus hemagglutinin-neuraminidase with influenza virus neuraminidase. J Virol 1993;67:2972-2980.

26 Gulati U, Hwang CC, Venkatramani L, Gulati S, Stray SJ, Lee JT, Laver WG, Bochkarev A, Zlotnick A, Air GM: Antibody epitopes on the neuraminidase of a recent $\mathrm{H} 3 \mathrm{~N} 2$ influenza virus (A/Memphis/31/98). J Virol 2002; 76;12274-12280.

27 Blick TJ, Sahasrabudhe A, McDonald M Owens IJ, Morley PJ, Fenton RJ, McKimmBreschkin JL: The interaction of neuraminidase and hemagglutinin mutations in influenza virus in resistance to 4-guanidinoneu5Ac2en. Virology 1998;246:95-103.

28 Hay AJ: Characteristics of Human Influenza $\mathrm{A} / \mathrm{H} 1 \mathrm{~N} 1, \mathrm{~A} / \mathrm{H} 3 \mathrm{~N} 2$ and $\mathrm{B}$ Viruses Isolated Sep 2007 to Feb 2008. Geneva, WHO, 2008.

$>29$ Skehel JJ, Wiley DC: Receptor binding and membrane fusion in virus entry: the influenza hemagglutinin. Annu Rev Biochem 2000;69:531-569.
30 Parrish CR, Kawaoka Y: The origins of new pandemic viruses: the acquisition of new host ranges by canine parvovirus and influenza A viruses. Annu Rev Microbiol 2005; 59:553-586.

31 Lindstrom S, Sugita S, Endo A, Ishida M, Huang P, Xi SH, Nerome K: Evolutionary characterization of recent human $\mathrm{H} 3 \mathrm{~N} 2$ influenza A isolates from Japan and China: novel changes in the receptor binding domain. Arch Virol 1996;141:1349-1355.

32 Lekcharoensuk P, Lager Kelly M, Vemulapalli $\mathrm{R}$, et al: Novel swine influenza virus subtype H3N1, United States. Emerg Infect Dis 2006;12:787-794.

33 Vigerust DJ, Ulett KB, Boyd KL, Madsen J, Hawgood S, McCullers JA: N-Linked Glycosylation attenuates H3N2 Influenza Viruses. J Virol 2007;81:8593-8600.

34 Nakajima K, Nobusawa E, Tonegawa K, Nakajima S: Restriction of amino acid change in influenza A virus H3HA: comparison of amino acid changes observed in nature and in vitro. J Virol 2003;77:10088-10098. 